\title{
ON THE ODONATA (INSECTA) FAUNA OF KOTTAYAM DISTRICT, KERALA, INDIA
}

\section{K.G. Emiliyamma}

Western Ghats Field Research Station, Zoological Survey of India, Annie Hall Road, Kozhikode, Kerala 670002, India

The Odonata (Insecta) fauna of Kerala revealed in scientific literature (Fraser, 1931, 1933, 1934, 1936; Peters, 1981; Lahiri \& Sinha, 1991; Prasad \& Varshney, 1995; Radhakrishnan \& Emiliyamma, 2003) refers to 137 species spread over 79 genera, 31 subfamilies within 12 families. Of these, only Rhinocypha (Heliocypha) bisignata (Selys) is so far credited to the Kottayam district proper. The present study deals with 31 species under 22 genera and seven families collected from the Kottayam district of Kerala, India.

Situated in the foothills of Cardamom and Pandalam hills of the southern Western Ghats, the Kottayam district of Kerala State lies between $9^{0} 15^{\prime}-9^{0} 42^{\prime} \mathrm{N} \& 76^{0} 22^{\prime}-76^{0} 59^{\prime} \mathrm{E}$ (Fig. 1). The rivers Muvattupuzha, Manimala and Meenachil form the drainage systems of this district.

The material studied forms part of a general faunal collection procured during the faunal surveys conducted in the district. Altogether 12 different localities were covered during the survey to gather a representative collection of odonates, the details of which are presented below. The material studied are deposited in the faunal depository of the Western Ghats Field Research Station, Zoological Survey of India, Kozhikode.

\section{Systematic Account}

1. Agriocnemis keralensis Peters

Agriocnemis keralensis Peters, Dtsch. Ent. Z. N.F., 28, heft I - III, Seite 93-108 (1981).

Diagnosis: Labrum non-metallic; superior anal appendages longer than inferiors second abdominal segment in male with broad black markings along with a pair of small greenish eyespot like spectacle mark on the hood of a cobra.

Material examined: 12 males, 10 females, 24-x-2000, Kidangoor, coll. P.M.

Sureshan

Distrbution: Kerala: Thiruvananthapuram and Kottayam (new record).

\section{Agriocnemis pieris Laidlaw}

Agriocnemis pieris Laidlaw, Rec. Indian Mus. vol. xvi, pp.179-180 (1919).

Diagnosis: Labrum non-metallic; in male, abdomen pale blue with black markings, segment 2 to 6 with well defined apical annules, segment 2 with an anchor shaped dorsal marking, segments 4 to 6 with subapical dorsal black fleur-de-lis spots narrowly confluent with the apical annules; in female, abdomen broadly marked with black on dorsum from segments 1 to 9 .

Material examined: 2 males, 29-xii-1998, Chalamattom, coll. K.G. Emiliyamma 2 males, 27-x-2000, Ponkunnam, coll. P.M. Sureshan.

Distribution: Southern India.

\section{Agriocnemis pygmaea (Rambur)}

Agriocnemis pygmaeum Ramb., Ins. Nevrop. p. 278 (1842).

Diagnosis: Labrum metallic blue; in male, the pterostigma pale yellow in the fore wings, black in the hind wings; anal appendages brick red colour; female robust than male, labrum non-metallic; pterostigma yellow in all wings; anal appendages brick red.

Material examined: 7 males, 5 females, 24-x-2000, Kidangoor; 5 males, 3 females, 29-x-2000, Kumarakom, coll. P.M. Sureshan.

Distribution: Throughout the Oriental region.

\section{Ceriagrion cerinorubellum (Brauer)}

Pyrrhosoma cerinorubellum Brauer, Verh. zool.- bot. Ges. Wien, vol.xv, p.511 (1865).

Diagnosis: In male, abdomen bright red at base and anal ends, black on dorsum in between; in female, abdomen similar to the male, but the end segments a duller brownish-red.

Manuscript 1338; Received 25 February 2005; Revised received 07 September 2005; Finally accepted 20 October 2005; Date of publication 21 November 2005

Material examined: 1 male, 3 female, 29-x-2000, Kumarakom; 6 males, 2 female, 31-x-2000, Velloor, coll. P.M. Sureshan.

Distribution: Throughout India.

\section{Ceriagrion coromandelianum (Fabricius)}

Agrion coromandelianum Fabr., Ent. Syst. Suppl. p.287 (1798).

Diagnosis: Abdomen bright citron-yellow, without markings in males; in female, abdomen uniformly olivaceous, with an ochreous or golden brown tint on dorsum. Material examined: 4 males, 2 females, 25-x-2000, Kanjirampara, coll. P.M. Sureshan.

Distribution: Throughout India.

6. Copera marginipes (Rambur)

Platycnemis marginipes Ramb., Ins. Nevrop. p. 240 (1842)

Diagnosis: In males, legs bright orange, the posterior two pairs of tibiae moderately broadly dilated; superior anal appendages only one-fourth the length of inferiors; in female, legs brownish-white or carneous, tibiae not dilated; posterior lobe of prothorax without spines.

Material examined: 3 males, 30-xii-1998, Chalamattom, coll. K.G. Emiliyamma. Distribution: Widely distributed throughout southern Asia.

7. Copera vittata (Selys)

Psilocnemis vittata Selys, Bull. Acad. Belg. (2) vol. xvi, p.170 (1863).

Diagnosis: In male, legs reddish, the two posterior pairs of tibiae very slightly dilated; superior anal appendages at least half the length of inferiors; in female, legs yellow, tibiae not dilated; posterior lobe of prothorax with a pair of divergent, slender, forwardly directed spines.

Material examined: 1 male, 29-xii-1998, Chalamattom, coll. K.G. Emiliyamma. Distribution: Western Ghats.

\section{Caconeura risi (Fraser)}

Indoneura risi Fras., Rec. Ind. Mus. vol. xxxiii, pp. 449, 469-471, fig.6, i (1931). Diagnosis: Under surface of head pale azure blue; pterostigma subquadrate black; superior anal appendages with a tiny sub-basal tooth.

Material examined: 3 males, 29-x-2000, Idamaruku, coll. P.M. Sureshan

Distribution: Kerala: Tamaracherry, Calicut district and Kottayam (new record).

\section{Vestalis apicalis apicalis Selys}

Vestalis apicalis Selys, Bull. Acad. Belg. (2) vol. xxxvi, p.612 (1873).

Diagnosis: In both sexes the ground colour of head, thorax and abdomen metallic green or blue; tips of wings black, pterostigma absent in all the wings. Material examined: 1 female, 28-x-2000, Bharananganam, coll. P.M. Sureshan. Distribution: Eastern Ghats, northeastern India and Western Ghats.

\section{Vestalis gracilis gracilis (Rambur)}

Calopteryx gracilis Rambur, Ins. Nevrop. p.224 (1842).

Diagnosis: Same colour as in V. apicalis; tips of wings hyaline; two rows of cells between origins of Cuii and IA.

Material examined: 1 male, 1 female, 29-x-2000, Idamaruku, coll. P.M. Sureshan Distribution: Western Ghats, Bihar, northeastern India, Andaman \& Nicobar islands and Eastern Ghats.

\section{Vestalis gracilis montana Fraser}

Vestalis gracilis amoena Fraser, J. Bombay Nat. Hist. Soc., vol.xxxiii, p. 583 (1929).

Diagnosis: Colour and tips of wings as in V.gracilis; only a single row of cells between Cuii and IA.

Material examined: 1 female, 29-x-2000, Idamaruku, coll. P.M. Sureshan. Distribution: Southern India.

\section{Rhinocypha (Heliocypha) bisignata (Selys)}

Rhinocypha bisignata Selys, Syn. Cal. p. 62 (1853).

Diagnosis: In male, mesothoracic triangle large and coloured pink; apical third of fore wings and hind wings opaque, hind wings marked with two series of violaceous vitreous spots, pterostigma black; in female, mesothoracic triangle black; wings entirely hyaline, tinted palely with yellow, pterostigma black with pale creamy center.

Material examined: 1 male, 2 females, 30-xii-1998, Chalamattom, coll. K.G Emiliyamma; 1 female, 29-x-2000, Kidangoor; 1 male, 1 female, 28-x-2000, Bharananganam; 3 males, 30-x-2000, Idamaruku, coll. P.M. Sureshan.

Distribution: Southern and peninsular India.

\section{Ictinogomphus rapax (Rambur)}

Diastatomma rapax Rambur, Ins. Nevrop. p.169 (1842)

Diagnosis: In both sexes thorax and abdomen black marked with yellow; discoida cells different shaped in fore and hind wings and reticulated; face black segment 8 with a broad yellow ring; superior anal appendages of male acute at apex.

Material examined: 2 males, 24-x-2000, Kidangoor; 1 male, 27-x-2000, Kanjirappally, coll. P.M. Sureshan.

Distribution: Throughout India.

14. Acisoma panorpoides panorpoides (Rambur)

Acisoma panorpoides Rambur, Ins. Nevrop. p. 28, pl.ii, fig.26 (1842).

C Zoo Outreach Organisation; www.zoosprint.org December 2005 I ISSN 0973-2535 (Print edition); 0973-2551 (O nline edition) 


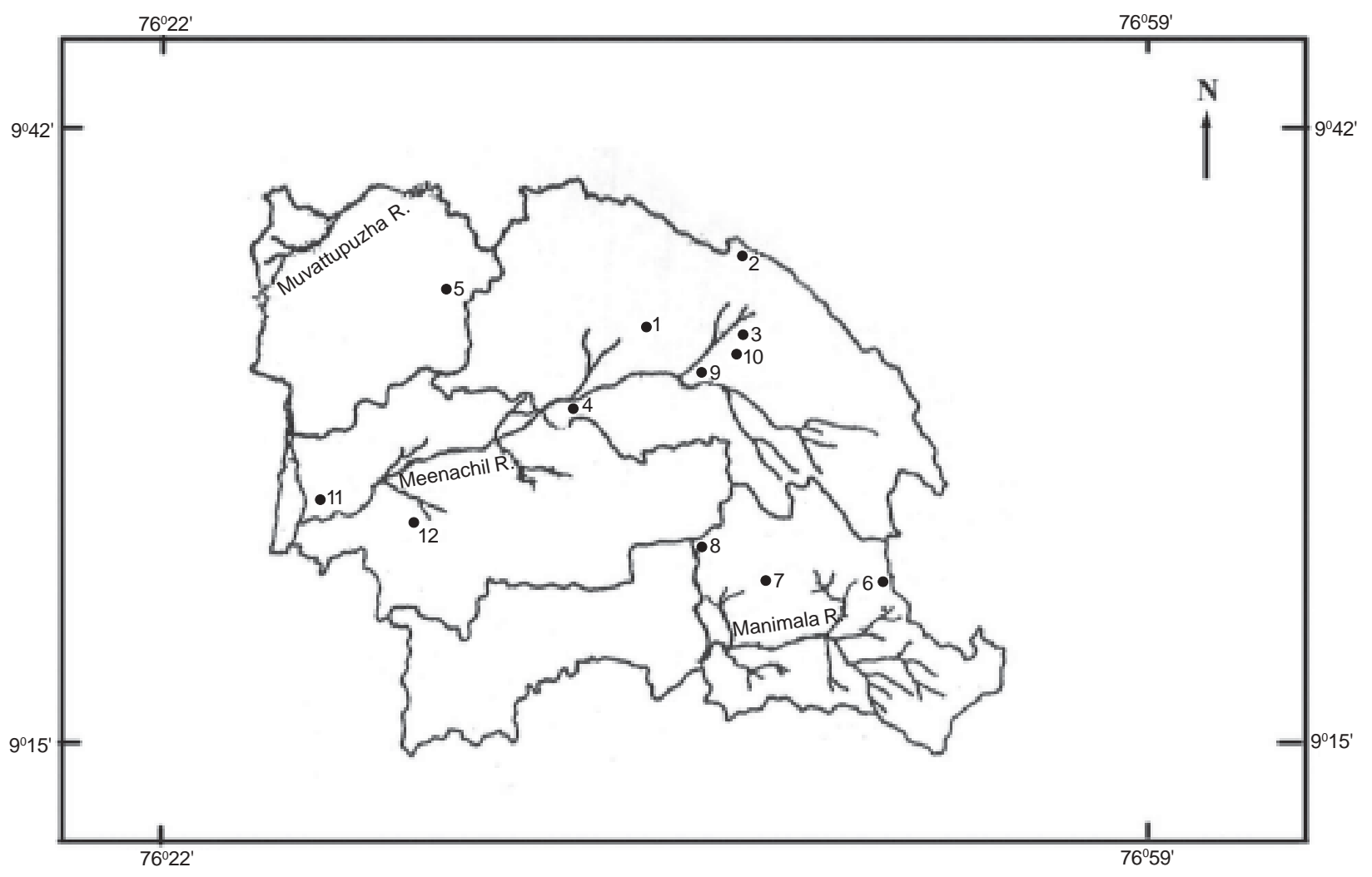

Figure 1. Map of Kottayam district showing collection locatlities

1 - Maryland; 2 - Elavizhapoonchira; 3 - Chalamattom; 4 - Kidangoor; 5 - Kanjirampara; 6 - Mundakayam; 7 - Kanjirapally; 8 - Ponkunnam; 9 - Bharananganam; 10 - Idamaruku; 11 - Kumarakom; 12 - Velloor

Diagnosis: Abdominal segments 1 to 5 laterally and dorso-ventrally widely dilated, then abruptly slimmed and cylindrical from segments 6 to 10; thorax azure blue, marked with black, the colour forming an intricate pattern of hieroglyphics on dorsum and sides.

Material examined: 1 male, 1 female, 15-xii-1998, Chalamattom, coll. K.G. Emiliyamma.

Distribution: Throughout India.

\section{Brachythemis contaminata (Fabricius)}

Libellula contaminata Fabricius, Ent. Syst. vol.ii, p. 382 (1793).

Diagnosis: In male, wings with a broad bright orange fascia extending from base to within 2 to 3 cells of pterostigma in both wings, reticulation reddish; in female, the bright orange fascia seen in the male absent, hind wing very palely tinted with yellow at extreme base.

Material examined: 1 male, 2 females, 27-x-2000, Kidangoor; 1 male, 30-x2000, Kanjirappally, coll. P.M. Sureshan.

Distribution: Through out India.

\section{Brachydiplax chalybea chalybea Brauer}

Brachydiplax chalybea Brauer, Verh. zool.- bot. Ges. Wien, vol. xviii, pp.173, 725 (1868).

Diagnosis: Frons metallic above; dorsum of thorax pruinosed white; sides of thorax and basal segments of abdomen ferruginous; bases of all wings burntbrown or golden brown.

Material examined: 3 males, 24-x-2000, Kumarakom; 1 male, 31-x-2000, Velloor coll. P.M. Sureshan.

Distribution: Assam, West Bengal and Kerala.

\section{Diplacodes trivialis (Rambur)}

Libellula trivialis Rambur, Ins. Nevrop. p. 115 (1842).

Diagnosis: Wings hyaline, without apical or basal marking, Cuii in hind wing widely separated from posterior angle of discoidal cell; adults pruinosed blue throughout, sub adults and tenerals greenish-yellow marked with black; anal appendages creamy yellow.

Material examined: 1 male, 20-xi-1998, Maryland, coll. K.G. Emiliyamma.

Distribution: Throughout India.

18. Neurothemis tullia tullia (Drury)

Libellula tullia Drury, III. Exot. Ins. vol. ii, pl. xlvi, fig.3, p. 85 (1773).
Diagnosis: Bases of wings in male, broadly black, edged outwardly with an opalescent white band; in female, the base of wings to just beyond node brigh amber yellow, subcostal space from base to node blackish brown, broadening at node into a large blackish brown spot nearly to the posterior border of wings, variably shaped in fore wing, curved like a sickle in the hind wing, apices of all wings opaque blackish-brown to middle or inner end of pterostigma.

Material examined: 2 males, 20-xi-1998, Maryland, coll. K.G. Emiliyamma; 1 male, 25-x-2000, Kanjirampara; 1 male, 1 female, 29-x-2000, Kumarakom; males, 30-x-2000, Kanjirappally; 4 males, 2 females, 31-x-2000, Velloor, coll. P.M. Sureshan.

Distribution: Bihar, Himachal Pradesh, Orissa and southern India.

\section{Orthetrum chrysis (Selys)}

Orthetrum chrysis Ris, Archivfur Natur. Bd. i, p.186, pl. ix, fig. 2 (1900).

Diagnosis: Males bright red; frons bright scarlet red; bases of wings with golden-amber coloured spot extending up to the first ante nodal nervure; lamina of male genitalia with a tuft of stiff black bristles; female bright ochreous throughout; wings without basal spot.

Material examined: 1 male, 15-xi-1998, Chalamattom, coll. K.G. Emiliyamma. Distribution: Himachal Pradesh, Orissa, Andaman Islands and Western Ghats.

\section{Orthetrum Iuzonicum (Brauer)}

Libellula luzonica Brauer, Verh. zool. - bot. Ges. Wien, vol. xviii, pp. 169, 732 (1868).

Diagnosis: Thorax pale olivaceous green dorsally, with broad reddish brown humeral stripe bordered anteriorly in black, pale olivaceous green laterally; thorax and abdomen pruinosed azure blue except at sides of abdominal segments 1, 2 and base of 3, which are bright yellow; Cuii in hind wing arising well away from the posterior angle of discoidal cell; female greenish-yellow with black markings as in subadult or teneral male.

Material examined: 1male, 29-xii-1998, Chalamattom, coll. K.G. Emiliyamma. Distribution: Throughout India.

\section{Orthetrum sabina sabina (Drury)}

Libellula sabina Drury, III. Exot. Ins. vol. i, pl. xlviii, fig.4, pp. 114, 115 (1770). Diagnosis: Both male and female greenish yellow marked with black; abdominal segments 1 to 3 enormously swollen dorso-ventrally as well as laterally, segments 4 to 6 narrow, cylindrical and segments 7 to 9 compressed laterally. Material examined: 1 male, 15-xi-1998, Chalamattom, coll. K.G. Emiliyamma; 1 
male, 25-x-2000, Kanjirampara, coll. P.M. Sureshan.

Distribution: Throughout India.

\section{Pantala flavescens (Fabricius)}

Libellula flavescens Fabricius, Ent. Syst. Suppl. p. 285 (1798).

Diagnosis: Both male and female wings long and broad at base, narrow and pointed at apices and with pale golden yellow spot at the base, pterostigma small, that of hind wing distinctly smaller than in the fore wing; membrane white; abdomen robust, dilated at basal segments, bright ochreous tinted with bright brick-red dorsally.

Material examined: 1 male, Chalamattom, 30-xii-1998; 1 male, 27-xii-1998, Elavizhapoonchira, coll. K.G. Emiliyamma; 2 males, 26-x-2000, Mundakayam; 1 female, 27-x-2000, Kanjirappally; 6 males, 30-x-2000, Kidangoor, coll. P.M. Sureshan.

Distribution: Widely and commonly distributed throughout India.

\section{Potamarcha congener (Rambur)}

Libellula obscura Rambur, Ins. Nevrop. 64 (1842).

Diagnosis: Thorax in adults black, pruinosed more or less densely and appearing dark violaceous or blackish-blue; in sub adults, yellow markings showing obscurely through the pruinescence; abdomen completely pruinosed in old adults, partially so in younger specimens; female resembles the sub adult or teneral male in colour and markings.

Material examined: 1 female, 16-xi-1998, Maryland, coll. K.G. Emiliyamma. Distribution: Throughout India.

\section{Rhodothemis rufa (Rambur)}

Libellula rufa Rambur, Ins. Nevrop. p. 71 (1842).

Diagnosis: Male brilliant red; eyes meeting only at a point; the discoidal field of wings beginning with a row of 3 cells and then continued as 2 cells; female golden brown; thorax with bright citron yellow stripe extending from front of dorsum backwards between the root of wings and up to the mid-dorsum of abdominal segments 1 to 4 ; this stripe split into two elongate narrow ante humeral stripes by the mid dorsal carina.

Material examined: 1 female, 30-x-2000, Kidangoor, coll. P.M. Sureshan. Distribution: Throughout India.

\section{Rhyothemis variegata variegata (Linnaeus)}

Libellula variegata Linnaeus, Amoenitates Acad. vol. 6: 412 (1763).

Diagnosis: Wings marked with black and amber yellow; male with whole of wings tinted yellow, fore wings with spots at node, discoidal cell, apex and at middle of Riii; hind wing with similar dark spots and two broad longitudinal basa bands; female with broader, shorter wings, fore wings hyaline from node to apex, basal half with broad black markings hind wing with broad irregular markings to as far distal as pterostigma, apex hyaline.

Material examined: 1 male, 1 female, 20-xi-1998, Maryland, coll. K.G. Emiliyamma; 1 male, 25-x-2000, Kanjirampara; 1 male, 27-x-2000, Kanjirappally 4 females, 29-x-2000, Kumarakom; 2 males, 1 female, 29-x-2000, Idamaruku; 1 female, 31-x-2000, Velloor, coll. P.M. Sureshan.

Distribution: Throughout India.

\section{Tetrathemis platyptera Selys}

Tetrathemis platyptera Selys, Mitt. Mus. Dresden, p. 316 (1878).

Diagnosis: Both sexes coloured black, marked with yellow; upper part and sides of frons and vesicle brilliant metallic prussian blue; discoidal cell of fore wing with its costal side markedly angulated, that of hind wing with its base widely distal to level of arc; fore wings faintly tinted with yellow at base, that of hind wing very broadly and deeply tinted.

Material examined: 1 male, 1 female, 16-xii-1998, Chalamattom, coll. K.G. Emiliyamma; 1 female, 26-x-2000, Mundakayam, coll. P.M. Sureshan.

Distribution: Throughout the submontane wet areas of India.

\section{Tholymis tillarga (Fabricius)}

\section{Libellula tillarga Fabricius, Ent. Syst. Suppl. p. 285 (1798).}

Diagnosis: In male, wings with a broad fan-shaped, smoky, golden-brown fascia extending from node to base of hind wing, bordered distally by a broad oval opalescent white spot; in female, the opalescent white spot absent and the golden- brown fascia very pale and obscure.

Material examined: 1 male, 30-x-2000, Kidangoor, coll. P.M. Sureshan. Distribution: Throughout India.

\section{Tramea limbata similata (Rambur)}

Libellula limbata Desjardins, Rapport soc. Maurice, I (1832).

Diagnosis: In both sexes, the base of hind wings with an extremely variable blackish-brown marking, not surround by a golden-yellow areola, the nervures in which are reddish; genital hamules in male much longer and greatly overlapping the lobe.

Material examined: 1 male, 25-x-2000, Kanjirampara, coll. P.M. Sureshan. Distribution: Southern India.

\section{Trithemis aurora (Burmeister)}

Libellula aurora Burmeister, Handb. Ent. vol. ii, p.859 (1839).
Diagnosis: In male, thorax and abdomen violaceous crimson; wings with crimson reticulation and broad amber yellow spot at the base with darker brown rays in sub costal and cubital spaces; in sub adults and tenerals, wings with yellow neuration; thorax yellow; abdomen bright ochreous; in female, purplish-brown; thorax and abdomen as in sub adult male; wings tipped with brown, basal marking pale, without dark rays in subcostal and cubital.

Material examined: 4 males, 15-xi-1998, Chalamattom, coll. K.G. Emiliyamma; 2 males, 27-x-2000, Kanjirappally, coll. P. M. Sureshan. Distribution: Throughout India.

\section{Trithemis festiva (Rambur)}

Libellula festiva Rambur, Ins. Nevrop. p. 92 (1842).

Diagnosis: In male, thorax and abdomen violaceous-black; base of hind wings with dark opaque brown mark, dark rays in sub costal and cubital spaces, neuration black; in female, thorax greenish-yellow and abdomen bright yellow marked with black; wings similar to that of male, but in adults broadly dark reddish brown at apices.

Material examined: 2 males, 28-xii-1998, Elavizhapoonchira, coll. K.G. Emiliyamma.

Distribution: Throughout India.

\section{Urothemis signata signata (Rambur)}

Libellula sanguinea Burmeister, Handb. Ent. 2: 858 (1839).

Diagnosis: Wings hyaline, with crimson reticulation; extreme base of fore wing golden amber; a broader dark amber coloured spot at base of hind wing extending variably distal wards to slightly beyond cubital nervure or to as far as base of discoidal cell, first antenodal nervure, and posteriorly in a curve to the tornal angle; in this spot, and framed by it, a blackish brown spot extending from cubital space posteriorly for a variable distance, the network of neuration over it bright ochreous or crimson; in most specimens a short, similarly coloured rays in the costal and sub costal spaces; in female, wings with basal markings variable, the blackish brown spot in anal area well separated from that in the cubital space, so that there are 3 distinct dark areas instead of 2 at base of hind wing.

Material examined: 1 female, 25-x-2000, Kanjirampara; 2 males, 29-x-2000, Kumarakom, coll. P.M. Sureshan.

Distribution: Throughout India.

\section{Discussion}

The current study presents an authentic record of 31 species of Odonata occurring in the Kottayam district of Kerala, India. Caconeura risi (Fraser) so far known only from Tamaracherry, Calicut district, Kerala and Agriocnemis keralensis Peters, hitherto known only from its type locality at Karamana, Trivandrum district, Kerala have now been collected from the Kottayam district after their original description in 1931 and 1981 respectively.

\section{REFERENCES}

Fraser, F.C. (1931). Additions to the survey of the odonate (dragonfly) fauna of Western India, with descriptions of nine new species. Records of the Indian Museum 33: 443-474.

Fraser, F.C. (1933, 1934, 1936). Fauna of British India including Ceylon and Burma: Odonata. Vols. 1-3. Taylor \& Francis, London.

Lahiri, A.R. and C. Sinha (1991). A review of Indian Chlorocyphidae (Insecta: Odonata) with additional notes on taxonomy and distribution for some species and description of a new subspecies. Records of the Zoological Survey of India 89(1-4): 257-268.

Peters, G. (1981). Trockenzeit-Libellen aus dem Indischen Tiefland. Deutsch Entomologische Zeitschrift (N.F.) 28: 93-108.

Prasad, M. and R.K. Varshney (1995). A checklist of the Odonata of India including data on larval studies. Oriental Insects 29: 385-428.

Radhakrishnan, C. and K.G. Emiliyamma (2003). Odonata (Insecta) of Kerala: A Systematic Database, pp.195-224. In: Gupta, R.K. (Editor) Advancements in Insect Biodiversity. Agrobios, Jodhpur.

\section{ACKnOWLedgement}

The author is grateful to Dr. J.R.B. Alfred, Director, Zoological Survey of India, Kolkata and C. Radhakrishnan, Officer-in-Charge, Zoological Survey of India, Kozhikode, for facilities and encouragement. 